\title{
Political Pedagogy towards Democratic Education: Educating Students to Care about Local and Global Injustice
}

\author{
Aaron Cooley \\ New England College
}

\begin{abstract}
And we have a name for this. It is called love. Isn't love precisely this kind of-like a cosmic imbalance. I was always disgusted by this notion of "I love the world"-universal love. I don't like the world. I don't know. I am basically somewhere between I hate the world or I am indifferent towards it. [unintelligible]. But the whole of reality, it's just it. It is stupid. It is just out there. I don't care about it. Love for me is an extremely violent act. It is not I love you all. It means I pick out something [pointing]. Again it is this structure of imbalance [Zizek wildly gestures his hands up and down like a teeter totter]. Even if this something is just a small detail, a fragile individual person, I say I love you more than anything else. In this quite formal sense, love is evil. (Zizek \& Taylor, 2005)
\end{abstract}

\section{Introduction}

The aim of this article is to explore how educators can assist students in developing attitudes that are engaged and sympathetic to local and global inequalities and injustices. Primarily, the work of Nel Noddings $(1984,1992,2002,2006,2007)$ on care and "caring about" will be used to examine how this goal might best be accomplished. The work of Slavoj Zizek (1989, 2001, 2004, 2006, 2008, 2008a) will also be addressed as it relates to Noddings' care project. My goal in reflecting on Noddings' work in this context is to better understand how college instructors can positively teach students (and pre-service teachers) to care about those individuals (and groups of people) that are separated from the students 
by a myriad of social, geographic, economic, and political factors. By working through the theoretical lens that Noddings provides, it is my hope to gain a greater sense of how to guide students to openness to and awareness of issues of local and global importance.

\section{Starting at Zizek}

The epigraph to this article may seem out of place. However, I would assert that Slavoj Zizek's comment is an outstanding, if unorthodox, place to jump into the discourse of care. My rationale for using one of Zizek's most popular Youtube rants to begin the discussion of Noddings' work on care and teaching students to care about issues of social and political import is based on the appearance that it seems so at odds with conventional common sense and possibly also with Noddings' views. Yet, this initial impression of incongruity, in my opinion, does not bear out. In fact, I think there is something remarkably similar in their positions. The point Zizek is making is one of his most profound and is right in front of all of us everyday-we prioritize who and what is important to us. Some things and some people are more important to us than others (usually family and friends) and simply saying we "love the world" does not cut it. This is similar to Noddings' contention that it is difficult to care for the world.

It seems that Zizek and Noddings have a common understanding and distaste for the paltry and emotionally impoverished view that love and care cannot be universalized in such a global manner without reducing the meaning of those terms beyond the constituent elements of their definitions. Further, it seems that Zizek and Noddings are both rejecting the platitude of universal love as being naïve and as a disappointing inversion of the true principle that supposedly makes up such statements. Zizek's provocative statement that "love is evil" may be shocking, but it is difficult to escape his dramatic assertion-we care more for some things and people than others. The implications of his statement lead us back to why Noddings' work is so vitally important to how we teach students to care about individuals and groups that are different from us and separated from us by proximity, gender, class, ethnic background, language, and intellectual tradition. The remainder of the article clarifies the importance of Noddings' work to post-secondary education. In the next sections, I will review Noddings' work on care and "caring about" and relate it to how educators may possibly guide students towards more benevolent attitudes on a global scale. 


\section{Noddings on Care and "Caring About"}

Nel Noddings' Caring: A Feminine Approach to Ethics and Moral Education (1984) is an outstanding achievement in relational moral theory. At the heart of Noddings' theory is a rootedness in lived experience that critiques the orthodox approach of abstracted, noetic moral schemes and that instead offers to vividly bring moral theory back into the real world. Noddings makes clear early on in this text why she thinks this feminine approach that relies on certain concreteness fills a historical void:

Women, in particular, seem to approach moral problems by placing themselves as nearly as possible in concrete situations and assuming personal responsibility for the choices to be made. They define themselves in terms of caring and work their way through moral problems from the position of one-caring. This position or attitude of caring activates a complex structure of memories, feelings and capacities. Further, the process of moral decision making that is founded on caring requires a process of concretization rather than of abstraction. An ethic built on caring is, I think, characteristically and essentially feminine-which is not to say, of course, that it cannot be shared by men, any more than we should care to say that traditional moral systems cannot be embraced by women. But an ethic of caring arises, I believe, out of our experience as women, just as the traditional logical approach to ethical problems arises more obviously from masculine experience. (Noddings, 1984, p. 8)

Here, in Noddings' theory, we have a grounded perspective for moral action that relies on always attempting to understand moral situations (and the individuals they involve) instead of simply trying to deduce how one should act by applying a moral law. Noddings' alternative flexibly stands against the historically dominant principle-based systems (see Lickona, 1991, 2004) well known to the public and ethicists, which are usually promoted by paragons of virtue such as conservative radio host and author William Bennett (1988, 1996, 2000, 2001). The acknowledgment and appreciation for the inherent complexity in attempts to act morally in Noddings' theory are of the utmost importance as they necessitate a desire to grasp how other individuals feel, act, and care.

On this point, Noddings shares several more key elements of her novel approach to moral relations: "When my caring is directed to living things, I must consider their natures, ways of life, needs, and desires. And, although I can never accomplish it entirely, I try to apprehend the reality of the other" (Noddings, 1984, p. 14). This move seems essential to how she understands the most important of human relations. Again, it also stands in marked contrast to the previously mentioned orthodox 
and principle-based systems. She continues this line of thought by reiterating the importance of attempting to know the other:

Apprehending the other's reality, feeling what he feels as nearly as possible, is the essential part of caring from the view of the one-caring. For if I take on the other's reality as a possibility and begin to feel its reality, I feel, also, that I must act accordingly; that is, I am impelled to act as though in my own behalf, but in behalf of the other. (Noddings, 1984, p. 16)

Clearly, this is much different from just recalling a moral dictate and acting accordingly. Of course, in thinking about how moral education is taught, we realize that the Bennett system is the one that has gained traction in America's public schools. However, attempts to employ Noddings' ideas in primary and secondary schools should be continued even with the familiar barriers of standards, accountability, and state mandates. Since these difficulties are substantially less present in higher education, I think it is essential to extend Noddings' work into the arena of post-secondary education (see Bok, 2006).

Now, if we think back to the Zizek epigraph, we can see the explicit connection between his comments and Noddings' views. We can now understand her position as expressing a similar distress (as Zizek) with the implosion of meaning of crucial terms - to paraphrase and extend Zizek's often employed metaphor (coffee without caffeine, meat without fat-ostensibly substance without substance). Many people now use the term love without meaning and say they care without any feeling. Nodding acknowledges:

We cannot love everyone. We cannot even care for everyone, and we do not need to love in order to care for. I have brushed aside "caring about" and, I believe, properly so. It is too easy. I can "care about" the starving children of Cambodia, send five dollars to hunger relief, and feel somewhat satisfied. I do not even know if my money went for food, or guns, or a new Cadillac for some politician. This is a poor second-cousin to caring. "Caring about" always involves a certain benign neglect. One is attentive just so far. One assents with just so much enthusiasm. One acknowledges. One affirms. One contributes five dollars and goes on to other things. (Noddings, 1984, p.112)

Of course, my assertion of a connection may raise red flags to some adherents of both scholars, and they may allege that I am doing theoretical violence to each theorist by suggesting such a connection. However, in linking them, I am not asserting that they are the same, but I am contending that they are commenting on a trend that they both find disturbing. Both of them see the developed status quo in human relations as being 
somewhat malformed and highly unproductive in creating a more socially progressive world. So, the connection as it appears is only strengthened and borne out in succeeding parts of Noddings' text. She asserts:

I am not condemning 'caring about.' We-all of us-give here and there and hope that others who care for will be enabled by our caring about . . . If by "love everyone" I mean that I would not without just cause harm anyone, that is acceptable. It is not trivial, for there are those who would harm others for their own worldly gain. But it is wildly ambiguous. If that is all I mean when I say that I love my child, or my husband, or my student, then each of these has, I think, been cheated. (Noddings, 1984, p.112)

What is not surprising is that Noddings' statements were not universally accepted by moral theorists and, as often happens when the truth is spoken and it unsettles a group's intellectual foundations, she received some criticism. She responded in The Challenge to Care in Schools: An Alternative Approach to Education (1992) with the following comment:

In Caring (1984), I wrote some paragraphs that upset many readers. I said that we (here in the United States, for example) could not, as individuals, be obligated to care for starving children in Africa because there is no way for most of us to see caring through to its completion. We might sympathetically send $\$ 10$ to Oxfam or some other relief organization, but we have no reliable method of knowing whether our money will be used to relieve hunger or to enrich greedy politicians. I still think this is an accurate descriptive account of a major difficulty in trying to care at a distance. I did not mean to suggest, however, that because we cannot really care in such situations, we are not obligated to do anything. (Noddings, 1992, p. 110)

So, in this instance, Noddings pushes back against critics who somehow misinterpreted her distinction between "caring for" and "caring about" as some sort of abdication of feeling towards disenfranchised and disadvantaged individuals and groups around the world. I am not sure how such mistakes could have been made considering the basis of her relational moral attitude is social responsibility. Further, these mistakes are confusing as Noddings' admiration for elements of liberalism are clearly for reducing unnecessary pain and suffering (see John Rawls, 1971/1999) and not the reckless promotion of individual freedom (see Robert Nozick, 1974). Therefore, it seems rather unfortunate that intellectual potshots were taken at her positions from such unwarranted angles.

Nevertheless, Noddings responded to these criticisms with her usual attitude of openness and dedication of trying to educate and persuade those who disagree or misunderstand what she said. She responded to the critics by clarifying and expanding her previous statements on some 
important theoretical distinctions on what one does when one cannot directly "care for":

But what are we obligated to do? Here we must move slowly. Perhaps the greatest danger to moral association with distant others is the tendency to sentimentalize. . . Education must address this tendency and press the questions: What are we obligated to do? What should we refrain from doing? (Noddings, 1992, p. 110-111)

Again, it must be said that Noddings is grounded to the facts and trusts personal and relational accounts about the plights of others. She must be concerned here with the problems and difficulties that can occur when various filters may obscure and distort the stories of individuals and groups around the world. She is careful to make clear that first impressions presented by the powerful elites in distant country may not provide the whole story. She contends, "At a distance, we judge not even by appearances but by reports of appearances. It is often so difficult to assess reality that we give up the task and simply take sides... Usually, if we are well intentioned, we take the side of the oppressed" (Noddings, 1992, p. 111). This statement makes clear again her desire to minimize suffering and, in this case, oppression.

Of course, it is difficult to move from an acknowledgement about the importance of "caring about" to some type of positive social action. For Noddings, not surprisingly, the answer lies in education. She puts this sentiment thusly:

This is not the place for a full philosophical analysis of these issues, but it is appropriate to say that such issues must be critically discussed in schools. An ethic of care counsels us to meet each living other in a caring relation. Human beings should not be branded as evil and therefore expendable because they belong to the side we oppose on a particular issue. When we attempt to act at a distance, we have to ask what effects our acts will have on concrete human beings. . . We can, with spurious good conscience, permit acts against those distanced that would appall us within our chosen moral community. (Noddings, 1992, p. 111-112)

It is here that I would assert that these critical discussions that Noddings wants to occur in K-12 education must continue to occur in higher education. As previously mentioned, I think that higher education may in fact be better positioned to confront these issues and get students to think about complicated and troubling examples of social inequality in new ways. It is my assumption that Noddings would agree on this point and likely agree to the assertion that teacher education programs would do well to provide forums for engaging pre-service teachers with 
the complexities of learning to care about marginalized individuals and populations both near and far from themselves.

Yet, Noddings is reluctant to believe in the simple notion that educating students with more knowledge about oppressed groups will necessarily lead to a positive change in social circumstances for either group. For her, just knowing is not enough to achieve the outcome of positive moral relations. She states:

One purpose of global education and multicultural education is to supply students with knowledge of other people and their customs. . . But knowledge alone is unlikely to establish caring relations. . . Knowing something about other cultures is important and useful, but it is not sufficient to produce positive relationships. (Noddings, 1992, p. 113)

It seems the crux of the problem for her would be the possibility of students detaching themselves from the knowledge they have of a situation, and it is here that the media's (mis)representations are forefront (see Bagdikian, 2002; Baker, 2007; Herman \& Chomsky, 2002). In effect, a student in primary school or college could know about genocide in Darfur and yet not have the ability to connect this passive knowledge to active social engagement (see Singer, 2002). I see her critique of knowledge not being enough for social action as a tacit critique of the Allan Bloom (1988) form of liberal education, which, of course, is related to the William Bennett style (1996) moral code. On this point, support comes directly from the text: "The attempt to achieve better relations through knowledge is part of the Cartesian quest for a method that I've been criticizing since chapter 1" (Noddings, 1992, p. 113).

Further, Noddings explains why she does not accept knowledge alone as being the answer to complicated moral interactions. Noddings asserts, "Knowledge is important, but it is best acquired in relation. . . A powerful source of motivation is an invitation from living others" (Noddings, 1992, p. 113). Here, she relies once again on relation, but in this case she is making a point on knowledge acquisition through relations to support the moral development she desires. For her, the focus is on gaining knowledge through relations with others. This is the most powerful form of knowledge production, but it is also difficult to obtain when direct integration and relationships with those distant others are impossible to forge.

\section{Care and Pedagogy}

Next, one can make an analogy to Erin Gruwell's (1999) pedagogy (real events made famous in the film Freedom Writers) of having her students meet and interact with Holocaust survivors to better understand those abhorrent events as well as to serve as a tool to learn more 
about their lives. Of course, this ideal scenario portrayed in the film is difficult to reproduce and, in most educational settings, the practicalities of creating direct relations among students and groups of marginalized individuals can be extremely difficult. This difficulty is acknowledged by Noddings as well:

At a physical distance the main problem is lack of completion; there is rarely a way for carers to receive the response of those for whom they would care. And so despite the best intentions of the carers, the relations themselves cannot be properly assessed as caring relations. . Caring at a distance is fraught with difficulties. (Noddings, 1992, p. 115)

However, an absence of the full capacity of these types of relations to achieve a caring relation does not mean that nothing can be done. Clearly, Noddings feels like much must be done; we just have to think about it differently than we think about caring relations. As such, she has some suggestions that would be moves toward a more socially sympathetic and empathetic world:

We can encourage caring attitudes at the community, national, and international levels. We can endorse the substantial exchange of people considered earlier, a public accounting of results achieved by relief efforts, the election of officials who seem to care. (Noddings, 1992, p. 123-124)

These macro-level prescriptions for Noddings step out from her usual focus on the most basic and concrete of relations, but this extension fits well with the overall thrust of her project-not to mention, these suggestions just make sense.

Yet, when she returns to the familiar territory of schools, she thinks students should further be engaged with the connections among their decisions and the rest of the world. Here, the focus harkens back to the classical golden mean of a middle ground between extremes:

At a more personal level, students can be encouraged to live moderately. This is a message rarely delivered in schools. More often we try to convince students that they can "make it big in America" if they study and do well in school. I am suggesting that students need to learn how to curb their appetites and to consider the possible effects of their own wealth on the rest of the world. (Noddings, 1992, p. 124)

Through this passage, we can see that Noddings connects the realms of caring for those that are close to us, but we cannot forget those individuals and groups who are further from us and simply ignore them. In short, the epistemic worlds of the cared-for and the cared-about should and do connect. What is also clear is that Noddings' own thinking on these connections has evolved over time. If we recall the early examples 
used in discussing "caring about," we remember that she was concerned about the use of donations making it to those in need. Concerns such as this still exist for some forms of aid such as some United Nations programs, but the nonprofit sector as a whole has become much more transparent than it once was. I think Noddings would agree that this sector has positively changed by making its efforts more efficient and thereby increasing its ability to provide assistance.

In Noddings' Starting at Home: Care and Social Policy (2002), her evolution in thinking about the topics at issue is made clearer:

The basic distinction between caring-for and caring-about remains important (although the particular language does not matter), but I think now that caring-about deserves much more attention. Indeed, caring-about may provide the link between caring and justice. (Noddings, 2002, p. 22)

For Noddings, it seems that "caring about" has emerged as a bridge from her main avenue of thought about care, the most important of our direct human relations, and the abstracted concept of liberal justice used by political philosophers. The connection that is crucial is how liberal philosophers have expounded on justice by neglecting the development of their rational actors. Often, it seems that, in liberal treatises, the adult rational actor comes into existence knowing what justice is and how to apply it to his or her life. What Noddings' work on care has done is to look at the elements that create a moral individual-an individual that cares for herself, her family, and her friends. Yet, it does not end there as Noddings' developing carer must eventually act in a greater social world and the liberal theorists' rational actor must have emerged from somewhere other than a bassinet left on the steps of a political science department building. Noddings' acknowledgement of this connection marks a great step in productively connecting these bodies of work toward progressive social attitudes in school and society.

It seems that there is much more theoretical work to be done in exploring the ideas of "caring for" and "caring about"-specifically in relation to the realms of philanthropy and volunteerism. Regardless, Noddings seems to now view these ideas as important to a more global attitude of care without retreating to the tired rhetoric of universal love and caring about everything. She describes this change and then connects it back to schooling:

Caring-about moves us from the face-to-face world into the wider public realm. . . Often we wish that we could care directly, but because that is impossible, we express our care in charitable gifts, in the social groups we support, and in our voting. These are not insignificant ways 
of responding, and they are ways that can be encouraged in schools. (Noddings, 2002, p. 22)

Yet, even with this rise in the value of "caring about," Noddings' pragmatic bend notes that a caring relation must materialize out of this situation. If this caring relation does not emerge, we will again fall back into hollow platitudes. She contends, "Caring-about is empty if it does not culminate in caring relations" (Noddings, 2002, p. 24). So, some things have changed for Noddings, but without the caring relation as a result, the "caring about" is just talk.

The final point to be made here is in connecting the internal moral territory to the external moral environment. This connection is important because Noddings desires to have our most intimate relationships to consist of care and to have this pattern manifest itself in creating positive social action in the world. She puts it thusly:

We would be foolish indeed to reject the hard-won rights that liberalism has brought us. Much of what has been learned in public life can be usefully applied to private life. The reverse is also true, however, and its consideration is long overdue. (Noddings, 2002, p. 301)

It seems Noddings wants us to consider how to live better by learning from our personal interactions and then applying them to the greater social world. In the end, the most noteworthy lesson seems to be we must learn to "care for" our closest relations, but we must now continue to learn to "care about" the broader social world in a fashion that is genuine, that is action oriented, and that does not equate these two sets of concepts, which would denigrate both of them.

\section{Conclusion}

It is my contention that Noddings' work on developing caring relations in students in primary and secondary schools must be extended into higher education. It seems vital to continue to develop these traits of not only "caring for," but also "caring about" in college students. Certainly some of this action oriented "caring about" is occurring across college and university campuses across the country, but often these socially progressive efforts emerge out of service organizations and not through courses. There are exceptions and some instructors are quite successful in integrating service into their courses (see Barber, 1992, 2007 ), but that does not mean that we can retreat from further calls to have more students learn to care about the experiences of others both near and far. In a deep sense, without awakening students to this vital task, we are shortchanging them of the most robustly rewarding part 
of higher education. Of course, many students enter higher education with hardened ideologies that reject social benevolence on every level except that of rhetorical support, but this should not stop progressive, justice-minded educators from attempting to find ways to persuade students to care about the world and all the people who inhabit it.

\section{References}

Bagdikian, B. H. (2002). The new media monopoly. Boston: Beacon Press.

Baker, C. E. (2007). Media concentration and democracy: Why ownership matters. New York: Cambridge University Press.

Barber, B. (1992). An aristocracy of everyone: The politics of education and the future of America. New York: Ballantine Books.

Barber, B. (2007). Con\$umed: How markets corrupt children, infantilize adults, and swallow citizens whole. New York: W.W. Norton \& Company Inc.

Bennett, W.J.(1988). Ourchildren and our country: Improving America's schools and affirming the common culture. New York: Simon \& Schuster.

Bennett, W. J. (1996). The book of virtues. New York: Simon \& Schuster.

Bennett, W. J. (2000). The policies for and the promise of an American education. Washington, DC: Heritage Foundation.

Bennett, W. J. (2001). The broken hearth: Reversing the moral collapse of the American family. New York: Doubleday.

Bloom, A. (1988). The closing of the American mind. New York: Simon \& Schuster.

Bok, D. (2006). Our underachieving colleges: A candid look at how much students learn and why they should be learning more. Princeton, NJ: Princeton University Press.

Gruewell, E. (1999). The Freedom Writers diary: How a group of extraordinary teens used writing to change themselves and the world around them. New York: Doubleday.

Herman, E., \& Chomsky, N.(2002). Manufacturing consent: The political economy of the mass media. New York: Pantheon.

LaGravenese, R. (2007). Freedom Writers. [Motion Picture]. Hollywood, CA: Paramount Home Entertainment

Lickona, T. (1991). Educating for character: How our schools can teach respect and responsibility. New York: Bantam.

Lickona, T. (2004). Character matters: How to help our children develop goodjudgment, integrity, and other essential virtues. New York: Simon \& Schuster.

Noddings, N. (1984). Caring: A feminine approach to ethics and moral education. Berkeley, CA: University of California Press.

Noddings, N. (1992). The challenge to care in schools: An alternative approach to education. New York: Teachers College Press.

Noddings, N. (2002). Starting at home: Caring and social policy. Berkeley, CA: University of California Press.

Noddings, N. (2006). Critical lessons: What our schools should teach. Cambridge, UK: Cambridge University Press. 
Noddings, N. (2007). When school reform goes wrong. New York: Teachers College Press.

Nozick, R. (1974). Anarchy, state, and utopia. New York: Basic Books.

Rawls, J. (1999). A theory of justice. Cambridge, MA: Belknap Press of Harvard University Press. (Original work published in 1971)

Singer, P. (2002). One world: The ethics of globalization. New Haven, CT: Yale University Press.

Zizek, S. (1989). The sublime object of ideology. London, UK: Verso.

Zizek, S. (2001). Did somebody say totalitarianism? London, UK: Verso.

Zizek, S. (2004). Organs without bodies: Deleuze and consequences. New York: Routledge

Zizek S. (2006). The parallax view. Cambridge, MA: MIT Press.

Zizek, S. (2008). In defense of lost causes. New York: Verso.

Zizek, S. (2008a). For they know not what they do: Enjoyment as a political factor. London, UK: Verso.

Zizek, S. [Star], \& Taylor, A. (Director). (2005). Zizek!. [Motion picture]. New York: Zeitgeist Films. 